\title{
COVID-19 Pandemic: Opportunity for a True Economic and Regional Integration of Africa
}

\author{
Modeste Ndaba Modeawi ${ }^{1}$, Clarisse Falanga Mawi ${ }^{2}$, Urbain Mazo Nyante ${ }^{3}$, Jacquie \\ Kangu Kobe ${ }^{4}$, Ruphin Djolu Djoza ${ }^{5}$, JP Mokombe Magbukudua ${ }^{6}$, Masengo Ashande \\ Colette $^{7}$, Gédéon Ngiala Bongo ${ }^{8}$, Muhammad Ridwan ${ }^{\text {* }}$, Koto-te-Nyiwa Ngbolua ${ }^{10}$ * \\ ${ }^{1,3}$ Faculty of Law, University of Gbado-Lite, Gbado-Lite, Democratic Republic of the Congo \\ ${ }^{2,8,10}$ Faculty of Science, University of Kinshasa, Kinshasa, Democratic Republic of the Congo \\ ${ }^{4}$ Higher Institute of Rural Development of Mbandaka, Mbandaka, Democratic Republic of the Congo \\ ${ }^{5,7,10}$ Faculty of Science, University of Gbado-Lite, Gbado-Lite, Democratic Republic of the Congo \\ ${ }^{6}$ Faculty of Agricultural Sciences, University of Gbado-Lite, Gbado-Lite, Democratic Republic of the Congo \\ ${ }^{7}$ Universitas Islam Negeri Sumatera Utara, Indonesia \\ jpngbolua@unikin.ac.cd
}

\begin{abstract}
According to official sources, the coronavirus pandemic that emerged in China in December 2019 has already infected more than 17 million and killed more than 666,850 people. Less impacted than the rest of the world, the Africa continent has nearly 890,000 confirmed cases as of July 30, 2020. According to the African Bank of Development, nearly 50 million Africans will be victims of extreme poverty as a result of the coronavirus pandemic; and this, following the global economic crisis due to this pandemic. It is shown that between 2020 and 2021, Africa will lose in terms of economic income 1/4 of trillion dollars and that a contraction of $3.4 \%$ of GDP would be noticed. The risk of decline is justified by the decline in oil production by the main exporting countries, notably Algeria, Nigeria and Angola; in addition to the decline in commodity prices on the world market, the volatility of global financial conditions and natural disasters. Even if some analysts believe that the effects of this pandemic are temporary on the economy of the states, it is clear to note that they are perceptible on the world economy in general. In Africa, the low rate of infection, which is 5\% since the emergence of the pandemic until July 30, 2020, is a favorable opportunity for the continent to recover and accelerate the process of its economic and regional integration.
\end{abstract}

Keywords: coronavirus; world economy; opportunity-integration-Africa

\section{Introduction}

The corona virus pandemic is one of the health crises of the century that Africa is facing. The countries of the continent had reported very few cases, about ten for some and none for others. However, as time goes by, the African continent finds itself with more and more cases, first exported from Europe and America, resulting in local contamination. The Ebola health crisis, which caused tens of thousands of deaths, has, on the other hand, provided countries with experience in crisis management. The measures taken by a large majority of African countries after the announcement of only a few cases was a proof of severity, because they are aware that they are not able to cope with the coronavirus if it spreads as in Europe and America [1].

Given that the political situation in some African countries remains constantly tense, the health management of such a crisis constitutes a barometer that could reconfigure the relationship between decision-makers and the population. Health crises affect all countries in the world, but the impact is greater on fragile states [2]. On the African continent, projections by the Economic Commission for Africa estimate that the crisis will plunge 
nearly 27 million people into extreme poverty. A $\$ 100$ billion fund is needed to protect and contribute to the shared prosperity of the continent. [3]. According to the African Bank of Development, nearly 50 million Africans will be victims of extreme poverty as a result of the corona virus pandemic; and this, as a result of the global economic crisis due to this pandemic, because between 2020 and 2021. Africa would lose in terms of economic income $1 / 4$ of trillions of dollars and a contraction of $3.4 \%$ of GDP would be noticed. The risk of decline would be justified by the decline in oil production by the main exporting countries, notably Algeria, Nigeria and Angola; in addition, the decline in the price of raw materials on the world market, the volatility of global financial conditions and natural disasters. The effects of the pandemic have hit the economies of African countries hard, and the slowdown in this area is a justification for this. The United Nations Economic Commission for Africa estimates that African countries should be prepared to see their growth halved to only $2 \%$ instead of the $4 \%$ originally projected. Thus, the revenues of countries that depend mainly on natural resources will be negatively impacted [1]. For Nigeria, for example, the reference price on which the budget was designed is $\$ 57$, while forecasts for the second and third quarters of 2020 place the price of a barrel at $\$ 30$. This economic situation would be a serious blow to the West African giant if sanitary measures were not taken so soon. The International Monetary Fund announced in February 2020 that the economies of African countries were in danger due to the decrease in demand from China, the continent's main trading partner, but also from Europe, which is very close to African countries [1]. Thus, the economic consequences of the epidemic could well be more important for Africa than the epidemiological impact because the economic growth of China, according to forecasts, will fall from $6.1 \%$ to $5.6 \%$ because of the coronavirus, which will certainly have negative consequences on the economies of African countries. Faced with this bleak picture, and following the example of other regional organizations like European Union, African countries must therefore think to health protection measures as well as economic responses within the framework of the African Union for which COVID-19 constitutes a major challenge that it must be able to meet for its regional economic integration.

\section{Research Methods}

Prior to this study, a literature review was conducted, based on data related to the (COVID-19 in the databases found on Google scholar (https://pages.semanticscholar.org/coronavirus-research); economic data related to African imports and exports, the wealth and potential of the African continent constitute the materials.

\section{Discussion}

To understand this topic, there is a need of clarifying some basic concepts and expressions:

\subsection{Integration}

Integration is the act of bringing together parts to form a whole, possibly more complete. African regional economic integration implies the assembly of all African countries in an organization, namely the African Union, for common objectives. 


\subsection{Coronavirus or Covid-19}

\section{a. Origin and Evolution}

Coronaviruses are viruses that cause Middle East Respiratory Syndrome (MERS), Severe Acute Respiratory Syndrome (SARS) and cold-like diseases. Indeed, on January 7 , 2020, China confirms the presence of several cases of Covid-19 of the Coronavirus family in the city of Wuhan; On January 30, 2020, in a very short time, the virus spreads until it reaches today 159 countries around the world. The World Health Organization declares the pandemic and declares an emergency of international scope. Not having taken into account the seriousness of the crisis from the beginning, several European countries, first Italy, then Spain and France, were overwhelmed [1]. As of today, almost all African countries have reported being affected by the virus, bringing the number of infected people on the continent to 892,116. However, the main foci of Covid-19 remain the Maghreb countries, namely Morocco, Egypt and Algeria, with South Africa taking the lead with almost 52\% of the African total. Worldwide, as of July 30, 2020, a total of 17,005,983 cases of infection and 666,857 people have died from COVID-19 [4].

\section{b. Contamination Statistics by Region}

\section{In America}

The virus came from China and reached the American continent via Europe. To date, America has 9,169,607 cases of infection, i.e. 53.91\% of the world total; the most affected countries on the continent are: The most affected countries of the continent are: the USA in the lead with 4,426,982 cases (48.27\%), followed by Brazil $(2,552,265$ or $27.83 \%)$; Mexico City: 408,449 or $4.45 \%$; Peru: 400,683 or $4.36 \%$ and Chile: 351,575 or $3.83 \%$. The rate of contamination for the rest of the countries of the continent is $11.26 \%$ as represented.

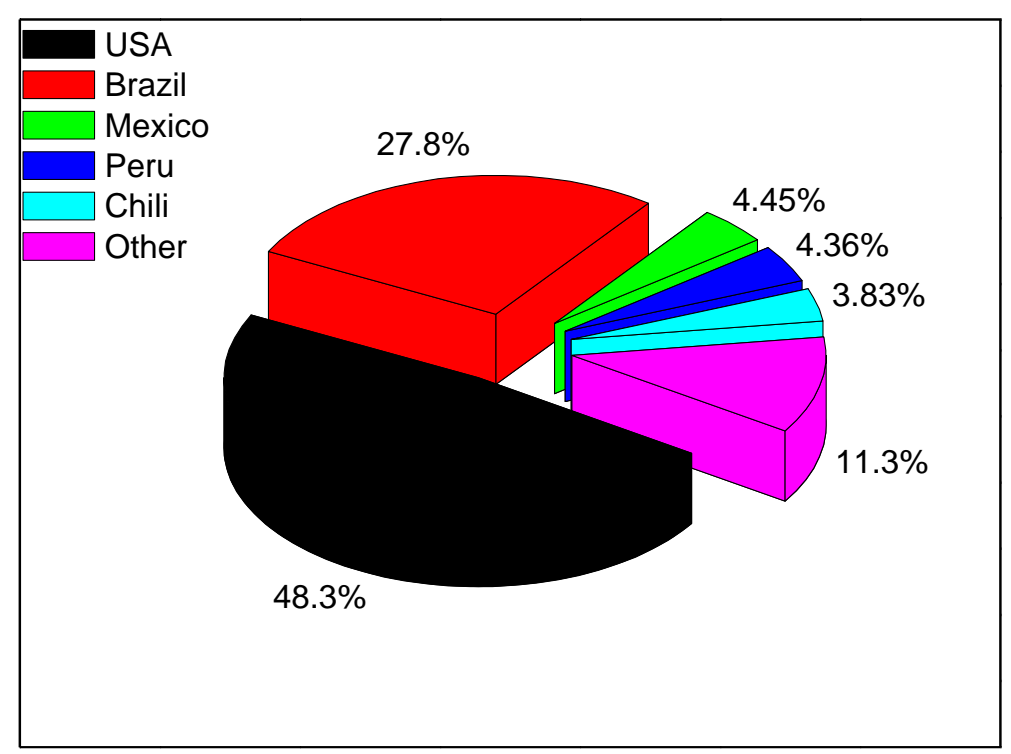

Figure 1. Corona Virus Infection Rates from the Onset of the Pandemic to July 30, 2020 in America

\section{In Europe}

Europe has several cases of contamination, which brings the total number of cases of contamination to $2,863,459$ or $16.83 \%$ of the world total; the most affected countries of the continent are Russia (828,990 or $28.95 \%$ ); United Kingdom (301,455 or 10.52\%); Spain $(282,641$ or $9.87 \%)$; Italy $(246 / 776$ or $8.61 \%)$ and Germany $(206,926$ or $7.22 \%)$. The contamination rate for the other countries of the continent is $34.83 \%$ [4]. 


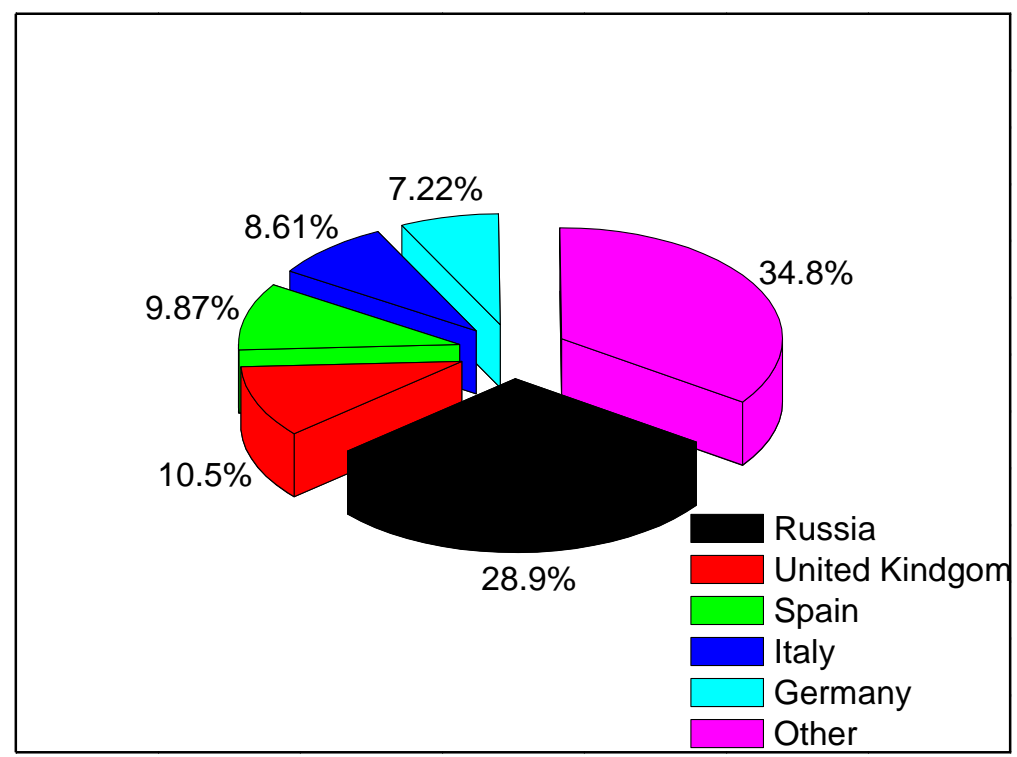

Figure 2. Contamination Rate Due to Corona Virus from the Start of the Pandemic to July 30, 2020 in Europe

\section{In Asia}

The virus first appeared in Wuhan, in the Chinese province of Hubei, and has spread throughout the Asian continent. To date, 4,062,743 cases have been confirmed, i.e. $23.89 \%$ of the world total. The most affected Asian countries are: India (1,583,792 or $38.98 \%)$; Iran $(298,909$ or $7.35 \%)$; Pakistan (277,402 or $6.82 \%)$; Saudi Arabia (272,590 or $6.70 \%)$ and Bangladesh $(232,194$ or $5.71 \%)$. The rate of infection in the other countries of the continent is $34.44 \%$ [4].

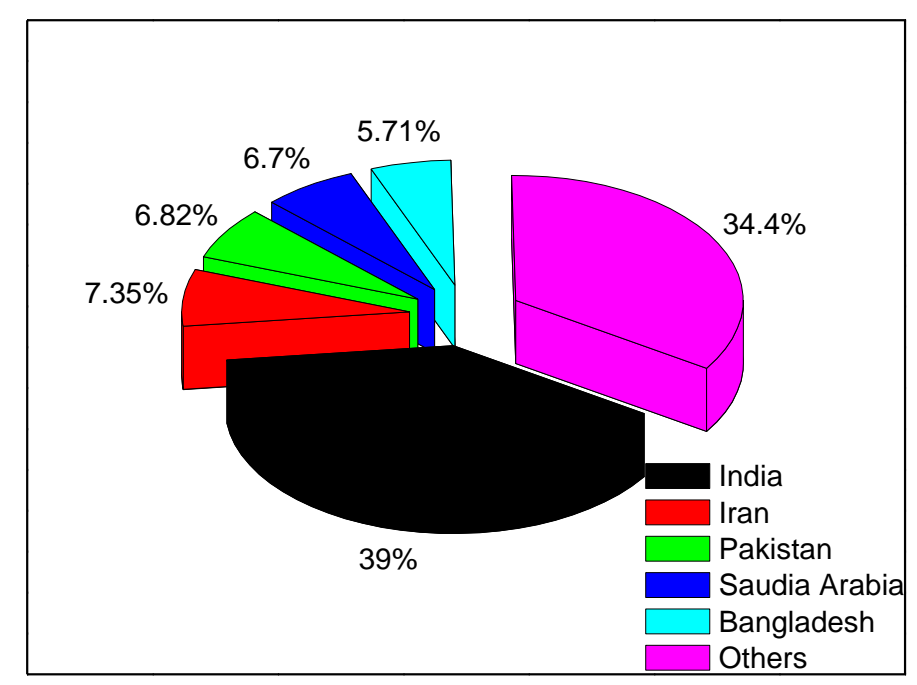

Figure 3. Coronavirus Infection Rates from the Onset of the Pandemic to July 30, 2020 in Asia

\section{In Africa}

In Africa, the first case of Covid-19 appeared in February 2020 in Egypt. The 54 countries of the continent are now affected by the virus, the main ones being: South Africa $(471,123$ or $52.80 \%)$; Egypt $(93,356$ or $10.46 \%)$; Nigeria $(42,208$ or $4.73 \%)$; Ghana $(35,142$ or $3.93 \%)$ and Algeria $(29,229$ or 3.27$)$; The other countries representing a rate of 
$24.81 \%$; Which brings for the whole continent to a total of 892,116 cases or $5.24 \%$ of the world [4].

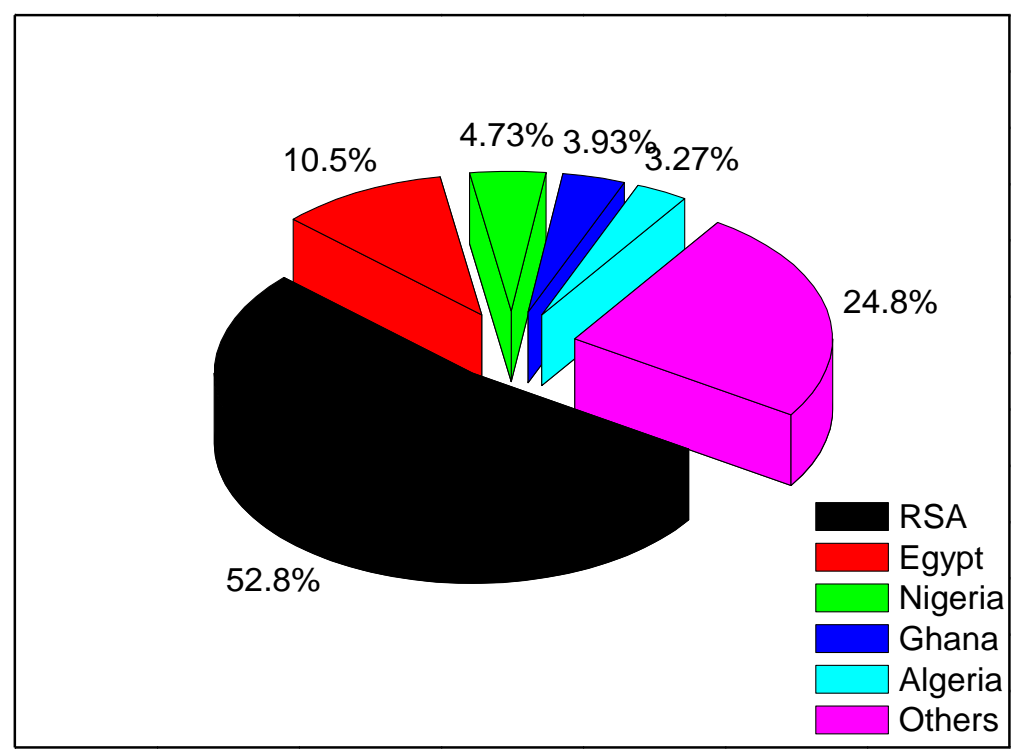

Figure 4. Coronavirus Infection Rates from the Onset of the Pandemic to July 30, 2020 in Africa

\section{In Oceania}

As of July 30, Oceania had a total of 17,362 cases of infection, i.e. $0.10 \%$ of the total worlwide, distributed among following countries, of which: Australia (15,582 or $89.74 \%)$; New Zealand (1,210 or $6.96 \%$ ); Guam (354 or 2.03\%); Papua New Guinea (63 or $0.36 \%$ ) and Polynesia (62 or $0.35 \%$ ) [4].

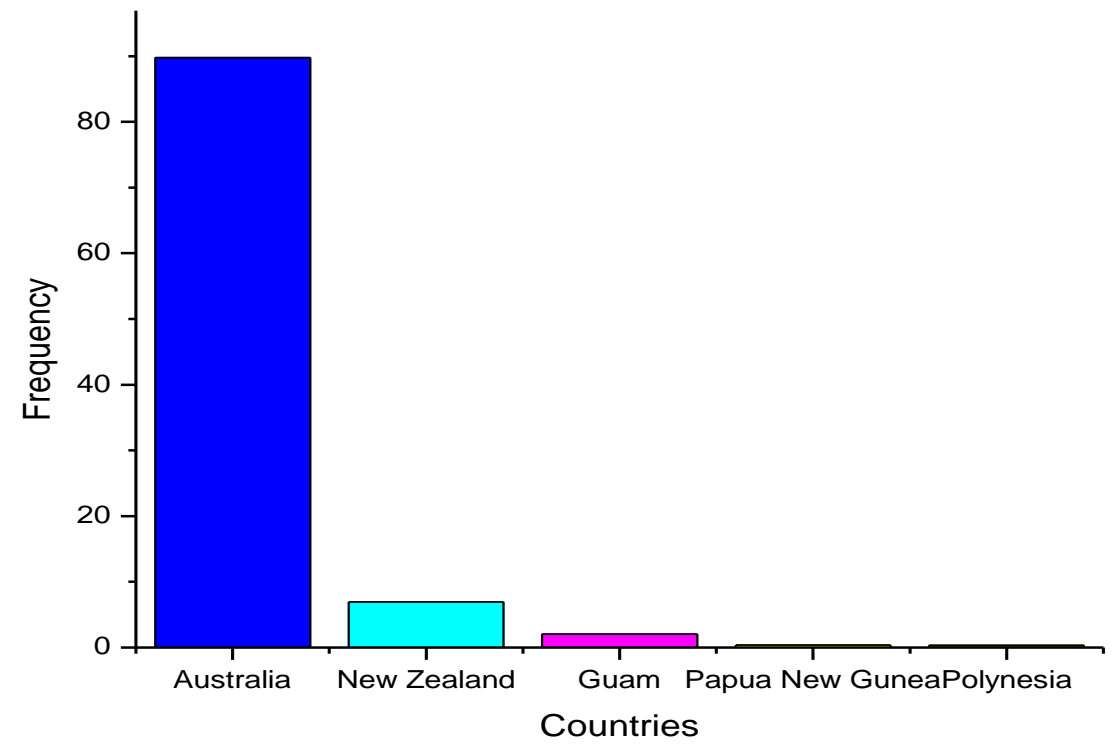

Figure 5. Corona Virus Infection Rates from the Onset of the Pandemic to July 30, 2020 in Oceania 
(i) Summary of the Rate of Contamination Due to COVID-19 in the World

The rate of contamination by COVID-19 in the world is as described above, namely America: 53.91\%; Asia: 23.89\%; Europe: 16.83\%; Africa: 5.24\% and Oceania: $0.10 \%$ and represented in the graph below:

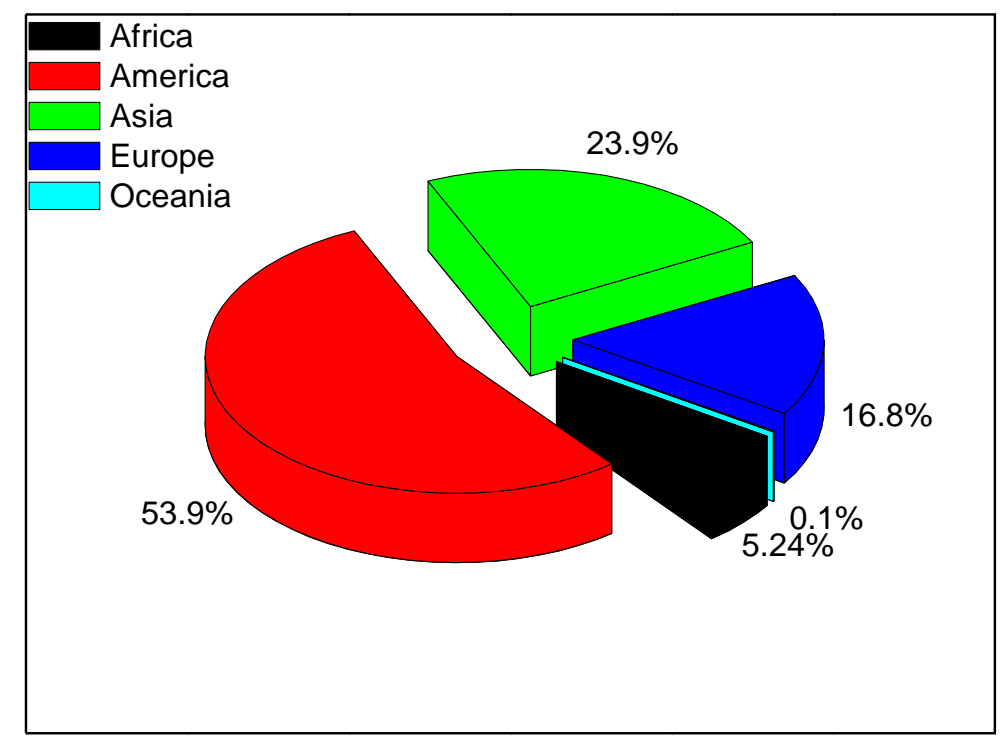

Figure 6. Contamination Rate Due to Corona Virus from the Start of the Pandemic to July 30, 2020

The evolution of the COVID-19 pandemic shows in the figure above that Africa and Oceania are the least affected.

\subsection{Africa's Economic Situation}

The overall economic performance of the continent continues to improve, with an estimated gross domestic product growth rate of 3.5 percent in 2018, comparable to 2017 , is up 1.4 percentage points from 2.1 percent in 2016. This African economic growth is expected to accelerate in the coming years to 4 percent in 2019, and 4.1 percent in 2020 . While this growth is higher than that of other emerging and developing countries, it is still insufficient to address the structural challenges of persistent current account and fiscal deficits and debt vulnerability. The challenge is therefore twofold: to improve the current growth trajectory and make it more job-creating [5].

\section{a. Africa's Macroeconomic Performance and Prospects}

Africa's economic growth continues to strengthen, reaching an estimated 3.5 percent in 2018, comparable to 2017 and up $1.4 \%$ from $2.1 \%$ in 2016. As a result, East Africa leads the way with estimated GDP growth of $5.7 \%$ in 2018, followed by North Africa at $4.9 \%$, West Africa at $3.3 \%$, Central Africa at $2.2 \%$, and Southern Africa at $1.2 \%$. In the medium term, growth is expected to accelerate to 4 percent in 2019 and $4.1 \%$ in 2020 . Of the 4 percent growth projected for Africa in 2019, North Africa is expected to account for 1.6 percentage points, or $40 \%$.

The fastest growing region, East Africa, is expected to grow by $5.9 \%$ in 2019 and $6.1 \%$ in 2020. In several African countries, GDP growth remains weak due to political uncertainties, notably in Burundi and the Comoros; growth in Central Africa, however, is gradually recovering, but remains below the average for Africa as a whole. This situation is 
justified by the recovery in commodity prices and improved agricultural production. This modest growth in the region is mainly due to the low level of development in South Africa, which affects neighboring countries [5].

\section{b. Africa's Natural Resources}

With an area of approximately 30.3 million square kilometers, Africa is undoubtedly the continent best endowed with natural resources. It is home to approximately 1.2 billion people, or $17 \%$ of the world's population, unevenly distributed over 55 states. Overall, it has a lower population density than the world average, with about 35 people per square kilometer compared to 47 percent globally. However, average population growth is very high, and according to population projections, Africa's population is expected to double by 2050. Indeed, the continent has 24 percent of the world's arable land and generates only 9 percent of agricultural production. While some are unable to exploit all of their land, others struggle to grow staple crops, resulting in the extreme famine episodes experienced in previous decades. Although the land has not yet unfolded its full potential, it is probably the African subsoil that abounds with the most wealth. Africa alone possesses more than 60 different types of minerals, accounting for one third of the world's mineral reserves, all minerals combined [6]. As an example, it is endowed with:

$\checkmark 90 \%$ of the world's platinum reserves;

$\checkmark 80 \%$ of coltan;

$\checkmark 60 \%$ of cobalt;

$\checkmark 70 \%$ of tantalum,

$\checkmark 46 \%$ of diamond reserves;

$\checkmark 40 \%$ of gold reserves and

$\checkmark 10 \%$ of oil reserves.

The paradox, however, is that although the continent is an energy powerhouse because of its resources, it is only an electrical dwarf in terms of consumption. The African population is equivalent to about $17 \%$ of the world's population, but consumes only $4 \%$ of the energy produced. However, to make up for this deficit and meet the growing needs of a growing population, its demand should increase by about $75 \%$ in the next twenty years. This is a boon that could well contribute to unlocking the potential for industrial growth [6].

Africa has the people and resources necessary for its development; also, all the necessary assets that can contribute to its economic and regional integration and that could make it an important player on a global scale. Africa has the means to achieve its ambitions [7].

\subsection{COVID-19: The Challenge of Genuine Regional Economic Integration in Africa}

In a world where the world's economies are becoming more internationalized and trade is being liberalized, only the most competitive (those with strong economic fundamentals and policy frameworks and diversified sources of growth) have a chance of carving out a place for themselves in the global economy. These are the "active globalizers," those that are arguably best positioned to mitigate the risks associated with global economic and financial integration, and thus to reap the full benefits of globalization. Despite the decline in import taxes across the continent's regional economic communities, various non-tariff and regulatory barriers continue to increase transaction costs and limit the movement of goods, services, labor, and capital across borders. These barriers include border delays, cumbersome customs and control procedures, extensive regulatory requirements, and, increasingly, the need for importers to comply with customs 
requirements. African states trade less frequently with each other than with the rest of the world. In Africa, the average cost of importing a container is about $\$ 2,492$, compared to $\$ 935$ in East Asia and the Pacific, and \$1,488 in Latin America and the Caribbean; intraregional trade, remains relatively rare and only accounts for about $15 \%$ of total trade in Africa, however in Europe it accounts for 68\% and in Asia, 58\% [8].

In addition to non-tariff barriers, the state of governance, the structure of production, the orientation of trade inherited from the colonial model of natural resource extraction, and constraints on supply also play a role. The latter include weak manufacturing, high cost of trade finance, limited access to information, and lack of or high cost of tradeenabling infrastructure. The African Continental Free Trade Area (AfCFTA) could not only improve market efficiency and reduce the cost of doing business by allowing for economies of scale, but it could also facilitate trade and investment and redefine the composition and direction of trade flows to Africa. Africa's economic prosperity depends on regional integration, which could improve regional security, as the expansion of international trade is often correlated with reduced levels of conflict [5].

\section{Conclusion}

The African economy can grow rapidly if it is not constrained by the effects of the various crises that plague most of its states. The continent faces multiple challenges; it is highly fragmented into a large number of landlocked countries and has generally poor transportation and communications infrastructure, especially in its central region. It is also home to more than two-thirds of the world's least developed countries (LDCs), a dozen of which have no access to the sea. Economic policies and regulations have sometimes exacerbated these disadvantages rather than addressed them. Despite growing revenues from resource exploitation and billions in large investment projects, according to the World Bank, $40 \%$ of Africa's population continues to live below the poverty line, or on less than \$2 a day, a figure that is rising despite notable progress in some countries. Because of its mineral wealth, Africa has long been robbed by foreign powers. A playground for colonial powers until the middle of the 20th century, Africa is now more than ever at the heart of bitter battles for control and influence between traditional powers.

Africa will only find its place in the world if it manages to organize itself. It is therefore up to the countries of the African continent to reorganize them within the African Union in order to dictate the rules of international cooperation so as not to perpetuate this spiral of dependence on external forces. It is therefore essential to rethink intra-African alliances through sub-regional organizations in order to be able to influence the geostrategic debate. To do this That the sub-regional organizations redefine their development objectives with particular emphasis on the economic and commercial aspects; That the African Union take ownership of the problems imposed by this health crisis in order to redefine the specific objectives of the Union by adapting them to the global economic context after COVID-19; That certain organs of the Union be abolished, which would be budgetary, in order to revitalize those that remain with a view to achieving the ultimate objective, which is the economic and regional integration of the African continent. 


\section{References}

Oumnia B (2020). Face au Coronavirus, l'Afrique se prépare au pire. https://www.africaportal.org

Flahaut A (2009). Gestion d'une crise sanitaire: l'exemple du chikungunya. Les Tribunes de la santé 1(22): 53-66.

Nyamugira BA, Borauzima ML, Ngongo MH (2020). COVID-19 en République démocratique du Congo : Comment financer la relance économique après la crise ? doi : 10.13140/RG.2.2.36424.06407/1.

Shannon S (2020). Ce que le Coronavirus signifie pour l'Afrique. Centre d'Etude stratégique en Afrique, (18 février). www.africacenter.org www.ecdc.europa.eu

Groupe de la BAD (2019), Perspectives économiques en Afrique 2019. https://www.afdb.org

Ramdoo I (2019). L'Afrique des ressources naturelles. International Institute for Sustainable of Development (IISD). https://www.iisd.org

Fofack H (2018). Une Afrique compétitive : L'intégration économique pourrait faire du continent un acteur à l'échelle mondial. Finance \& Development : International

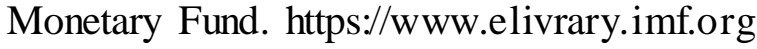

